\title{
SOME BEHAVIOURAL ASPECTS ON THE Hemidactylus SPECIES OF BANGLADESH
}

\author{
Rabbe, M. F., M. F. Jaman, M. M. Rahman and M. M. Alam \\ Department of Zoology, University of Dhaka, Dhaka - 1000, Bangladesh
}

\begin{abstract}
Hemidactylus is a taxonomically complex genus and little is known about its feeding and breeding behavior in Bangladesh. Most of the species of this genus have a preference to live within human habitations, and play an important role in ecosystem, controlling insect pest population. Their breeding strategy is almost similar with each other and associated with their body structure. Review of literature found that there is a relationship between life history pattern and their reproductive biology. They lay two eggs per clutch usually and the highest egg number (12) has been recorded for $H$. frenatus. Strong significant positive correlation $(\mathrm{r}=$ 0.91 ) was found for preclaocal-femoral pores and egg number. Besides, significant negative correlation was found for average female body size and egg number $(r=0.96)$. Previous work and observation records showed that feeding habit is almost similar among all species of Hemidactylus and dipteran insects were the mostly consumed food item.
\end{abstract}

Key words: Hemidactylus; Feeding; Breeding ecology; Life history.

\section{INTRODUCTION}

One of the most diverse lizard genus Hemidactylus (Oken 1817) comprises of 144 species (Uetz et al. 2016), widely distributed in the warmer parts in the tropics and subtropics of Asia, Africa, and the Pacific as well as in Mediterranean Europe, and northern South America (Bauer et al. 2010, Carranza and Arnold 2012). According to Global Biodiversity Information Facility (www.gbif.org), 32221 georeferenced records of Hemidactylus genus have been so far recorded till $13^{\text {th }}$ October 2018. The adaptive life history and reproductive behavior of this genus have facilitated its wide distribution with high species diversity in different corners of the world. About 28 species have been reported from the Indian subcontinent and 13 of them are endemic to this region (Bansal and Karanth 2010). Of these, Bangladesh harbors six species of this genus under the family Gekkonidae (Chakma 2009). The georeferenced records of the species of Bangladesh according to GBIF are: 13,187 for H. frenatus, 933 for H. garnotii, 866 for $H$. platyurus, 677 for H. brookii, 292 for $H$. bowringii, and 235 for $H$. flaviviridis. Hemidactylus genus in Bangladesh had been assessed by the IUCN Bangladesh (2015) and all of them are considered as least concern. The studies of Chakma (2009), Hasan et al. (2014) and IUCN BD (2015) suggest that most of the species of Hemidactylus are found in the northeastern and southeastern part of Bangladesh whereas $H$. frenatus is widely distributed and $H$. flaviviridis is found throughout the country except the Sundarbans. A new distribution record of $H$. bowringii in the northwestern Bangladesh has been reported by Rabbe et al. (2017).

Taxonomically the species of Hemidactylus is difficult to identify and chromosomal studies have been done for the same species in several times to eradicate ambiguity (Carranza and Arnold 2006). However, the study of Carranza and Arnold (2006) suggest that differences of external features like size of body, tail structure, ratio of the head, body and limbs, color variation in dorsal and ventral sides exist in different species. Furthermore, bulks of studies have been done on different aspects of the species around the world but no extensive work has been done on this genus in Bangladesh. Reptile population including lizard is facing different types of threats and their population is gradually declining. Six types of factors, such as habitat loss and degradation, invasive species, diseases, pollutants and agrochemicals, unsustainable use, and global climate change are causing the decline of reptile population (Gibbons et al. 2000). Some species of reptiles can also be a threat to others and it is likely for the species which can adapt themselves easily both in urban areas and human habitations. The work of Vanderduys and Kutt 
(2012) on Asian house gecko (Hemidactylus frenatus) suggests that the species can invade mother habitats, eradicate native species and carry diseases. So, it is important to know the breeding biology of the species along with different types of surviving strategies, restriction of their distribution and their protection from different kinds of threats. The reproduction of lizards is associated with season, environmental factors and natural selection (Al-Amri 2012). The climatic condition and anthropogenic factors provide suitable habitats for the reproduction of all species of lizard of Bangladesh. Unfortunately, no reproductive work has been reported so far from Bangladesh. In Bangladesh, research on feeding mechanism and feeding behavior of the species of this genus is scanty. Information from direct observation show that Hemidactylus spp. consume large number of harmful insects. No study on the evaluation of this genus in terms of controlling pest population and diseases carrying insect has been done so far. An attempt was taken to review some behavioural studies of Hemidactylus genus in Bangladesh.

\section{MATERIAL AND METHODS}

Data were collected from previously observed records and secondary sources such as extensive review of literatures and published articles from different sources. The data of breeding biology of Hemidactylus were collected from Church (1962), Sanyal and Prasad (1967), Mitchell and Zug (1988), and Al-amri (2012). Breeding data were noted as egg number, incubation period, precloacal pores and female size. We also collected information on habits, habitats and life history patterns of Hemidactylus which includes direct observation, morphometric studies, gut analysis and sampling (Zug et al. 2007, Naher et al. 2013, Tkaczenko et al. 2014, Hasan et al. 2014). The data were analyzed employing statistical package R-3.5.1 and Pearson correlation coefficient of different parameters was calculated.

\section{RESULTS AND DISCUSSION}

The species of Hemidactylus genus are characterized by having medium body size, sexual dimorphism, and more or less similar breeding strategy among them (Table 1). H. garnotii is a parthenogenetic species and data for the reproduction of $H$. bowringii was insufficient. So, data were analyzed excluding this two species. Among the six relationships, four (egg number and precloacal pores, egg number and female size, precloacal pores and female size, and precloacal pores and incubation period) are strongly related and the rest two relationship (incubation period and egg number, and incubation period and female size) are weak (Fig. 1a).

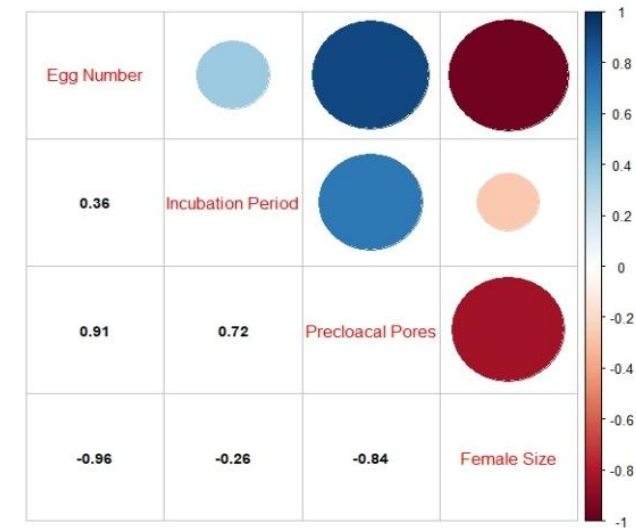

a

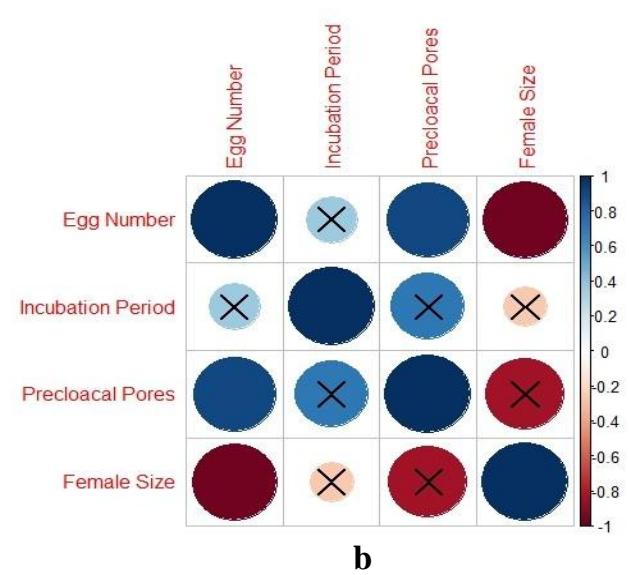

b

Fig. 1. a. Correlation value in between different parameters. b. Significance of Correlation (p-value) in between different parameters and statistical analysis set at $\mathrm{p}>0.5$ level of significant. 
Significant strong correlation was found between precloacal pores and egg number $(\mathrm{r}=0.91)$ and female body size and egg number $(r=0.96)$ (Fig. 1a and $b$ ). The other correlations (incubation period and egg number, incubation period and precloacal pores, incubation period and female size, and precloacal pores and female size) were not significant in Hemidactylus (Fig. 1b).

\section{Life History and Reproduction}

$H$. flaviviridis is the largest species with $90 \mathrm{~mm}$ snout vent length (SVL) and others SVL ranges from 34 to $66 \mathrm{~mm}$ (Zug et al. 2007, Hasan et al. 2014). The average SVL of the male of six species of Hemidactylus is $56.12 \mathrm{~mm}$ and female is $53.86 \mathrm{~mm}$ (Table 1). So, the average body size of male is larger than female. The largest and the smallest tail length are observed in $H$. flaviviridis and $H$. bowringii with a measurement of $92 \mathrm{~mm}$ and $50 \mathrm{~mm}$, respectively and the average tail length of the six species of Hemidactylus is $69.5 \mathrm{~mm}$ (Hasan et al. 2014).

Table 1. Some important characteristics (morphological and reproductive) according to different authors.

\begin{tabular}{|c|c|c|c|c|c|c|c|}
\hline \multicolumn{2}{|c|}{ Species Name } & H. bowringii & H. brookii & H. flaviviridis & H. frenatus & H. garnotii & H. platyurus \\
\hline \multirow{3}{*}{$\begin{array}{l}\text { SVL } \\
(\mathrm{mm})\end{array}$} & Adult & $34-51$ & $45-65$ & 90 & $42-59$ & $49-66$ & $47-58$ \\
\hline & Male & $34.5-49$ & $50.2-65$ & $68-80.8$ & $47.8-58.6$ & - & $49.2-58.1$ \\
\hline & Female & $35.6-50.7$ & $45.06-61.7$ & $71.1-79.3$ & $42.5-49.1$ & 56.5 & $47.5-50.7$ \\
\hline \multicolumn{2}{|c|}{ Tail length (mm) } & 50 & 70 & 92 & 70 & 70 & 65 \\
\hline \multicolumn{2}{|c|}{ Sexual orientation } & $\begin{array}{l}\text { Sexually } \\
\text { dimorphic }\end{array}$ & $\begin{array}{l}\text { Sexually } \\
\text { dimorphic }\end{array}$ & $\begin{array}{l}\text { Sexually } \\
\text { dimorphic }\end{array}$ & $\begin{array}{l}\text { Sexually } \\
\text { dimorphic }\end{array}$ & $\begin{array}{l}\text { Partheno- } \\
\text { genetic }\end{array}$ & $\begin{array}{l}\text { Not sexually } \\
\text { dimorphic }\end{array}$ \\
\hline \multicolumn{2}{|c|}{$\begin{array}{l}\text { Precloacal-femoral } \\
\text { pores }\end{array}$} & $18-27$ & $11-16$ & $5-7$ & $28-36$ & 0 & $36-40$ \\
\hline \multicolumn{2}{|c|}{ Egg Number } & - & $8^{*}$ & 4 & 12 & 6 & $10^{*}$ \\
\hline \multicolumn{2}{|c|}{$\begin{array}{l}\text { Incubation period } \\
\text { (days) }\end{array}$} & 35 & 39 & $36-39$ & 42 & - & 90 \\
\hline \multicolumn{2}{|c|}{ References } & $\begin{array}{l}\text { Zug et al. } \\
\text { 2007, Islam } \\
\text { 2009, Hasan et } \\
\text { al. 2014 }\end{array}$ & $\begin{array}{l}\text { Mitchell and } \\
\text { Zug 1988, } \\
\text { Zug et al. } \\
2007, \text { Chakma } \\
2009, \quad \text { Hasan } \\
\text { et al. } 2014\end{array}$ & $\begin{array}{l}\text { Sanyal and } \\
\text { Prasad 1967, } \\
\text { Al-amri2012, } \\
\text { Hasan et al. } \\
2014\end{array}$ & $\begin{array}{l}\text { Yamamoto and } \\
\text { Ota 2006, Zug } \\
\text { et al. 2007, } \\
\text { Chakma 2009, } \\
\text { Hasan et al. } \\
2014\end{array}$ & $\begin{array}{l}\text { Walter and } \\
\text { Meshaka } \\
\text { 1994, Zug et } \\
\text { al. 2007, } \\
\text { Hasan et al. } \\
2014\end{array}$ & $\begin{array}{l}\text { Church 1962, } \\
\text { Zug et al. } \\
\text { 2007, Hasan } \\
\text { et al. } 2014\end{array}$ \\
\hline
\end{tabular}

* eggs counted from oviduct

All the studied species of this genus have precloacal-femoral pores except $H$. garnotii (Zug et al. 2007) probably because all of them are females and reproduce through parthenogenesis. The highest precloacal femoral pores (average $=38$ ) has been recorded for $H$. platyurus and 10 eggs have been counted from oviduct whereas $H$. flaviviridis possesses the lowest number of precloacal femoral pores (average $=6$ ) and produces the lowest number of eggs among the six species (Table 1). Relationship of pores and egg number is positive (Fig. 1a) which means that the presence of more pores in females attracts more males to copulate and the increased probability of laying more number of eggs.

It was reported that four species are sexually dimorphic (viz. $H$. frenatus, $H$. flaviviridis, $H$. bowringii, and H. brookii), H. garnotii parthenogenetic and H. platyurus not dimorphic (Zug et al. 2007, Hasan et al. 2014). Zug et al. (2007) considered some morphological characteristics to express sexual dimorphism and some of these were: snout-vent length, crus length, fore-arm length, head length, jaw width, snout-eye length, snout-fore limb length, trunk length etc. Sexual dimorphism is absent in $H$. 
platyurus as the measurement and proportions of different morphological characters showed least variability between males and females (Zug et al. 2007).

All species of Bangladesh are oviparous and lay two eggs in first clutch (Chakma and Islam 2009). The highest number of clutch and egg has been reported for H. frenatus by Yamamoto and Ota (2006). The analysis shows that correlation between female body size and egg number is negative (Fig. 1a). This means that the number of egg laying decreases with the increase of female body size. Usually it is expected that when female body size increases the potentiality of laying eggs would also increase. The source of collecting egg number data was different like counting from oviduct and counting from laid eggs. Positive relationship may be expected if data can be collected from similar source, but the previous researches on reproduction are not sufficient. There is a positive relationship between incubation period and egg number (Fig. 1a) which means when the egg number increases incubation period also increases. Six types of correlation between different parameters of breeding in Hemidactylus were analyzed and among them only two correlations are found significant (Fig. 1b). Data of incubation period of $H$. garnotii and egg number of $H$. bowringii have not been found.

\section{Ecology and Feeding Behavior}

Habitat preference in Hemidactylus is not very diverse being saxicolous, arboreal or semi-arboreal and a preference to inhabit human habitation (Table 2). Chakma (2009), Islam (2009) and Hasan et al. (2014) found that all six species of Hemidactylus prefer human habitation and except $H$. brookii all are arboreal or semi-arboreal. Hasan et al. (2014) suggest that all are commensalistic and nocturnal in habit.

Table 2. Currently recognized species of Hemidactylus genus and their habit and food preferences.

\begin{tabular}{|c|c|c|c|c|c|c|c|}
\hline \multicolumn{2}{|c|}{ Species Name } & H. bowringii & H. brookii & H. flaviviridis & H. frenatus & H. garnotii & H. platyurus \\
\hline \multicolumn{2}{|c|}{ Authority } & Gray 1845 & Gray 1845 & Ruppell 1835 & $\begin{array}{l}\text { Dumeril and } \\
\text { Bibron } 1836\end{array}$ & $\begin{array}{l}\text { Dumeril and } \\
\text { Bibron } 1836\end{array}$ & Schneider 1792 \\
\hline \multicolumn{2}{|c|}{ English Name } & $\begin{array}{l}\text { Oriental Leaf- } \\
\text { toad Gecko }\end{array}$ & $\begin{array}{l}\text { Brook's } \\
\text { House Gecko }\end{array}$ & $\begin{array}{l}\text { Yellow-green } \\
\text { House Gecko }\end{array}$ & $\begin{array}{l}\text { Common } \\
\text { House Gecko }\end{array}$ & $\begin{array}{l}\text { Garnot's } \\
\text { Gecko }\end{array}$ & Flat-tailed Gecko \\
\hline \multicolumn{2}{|c|}{ Local Name } & Choto Tiktiki & Chiti Tiktiki & Goda Tiktiki & Mosrin Tiktiki & Dola Tiktiki & Chepta-leji Tiktiki \\
\hline \multirow{3}{*}{ 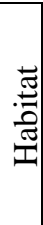 } & Saxicolous & & $\sqrt{ }$ & & $\sqrt{ }$ & & $\sqrt{ }$ \\
\hline & $\begin{array}{l}\text { Arboreal/ } \\
\text { semi-arboreal }\end{array}$ & $\sqrt{ }$ & & $\sqrt{ }$ & $\sqrt{ }$ & $\sqrt{ }$ & $\sqrt{ }$ \\
\hline & $\begin{array}{l}\text { Human } \\
\text { habitation }\end{array}$ & $\sqrt{ }$ & $\sqrt{ }$ & $\sqrt{ }$ & $\sqrt{ }$ & $\sqrt{ }$ & $\sqrt{ }$ \\
\hline \multirow{2}{*}{$\frac{.7}{\tilde{T}}$} & Activeness & Nocturnal & Nocturnal & Nocturnal & Nocturnal & Nocturnal & Nocturnal \\
\hline & Feed on & Insects & $\mathrm{Hy}, \mathrm{O}, \mathrm{C}, \mathrm{I}, \mathrm{A}$ & $\mathrm{O}, \mathrm{I}, \mathrm{A}, \mathrm{L}$ & $\begin{array}{l}\text { L, C, A, D, Hy, } \\
\mathrm{O}, \mathrm{He}, \mathrm{Z}\end{array}$ & Insects & $\mathrm{D}, \mathrm{H}, \mathrm{L}$ \\
\hline \multicolumn{2}{|c|}{ References } & $\begin{array}{l}\text { Zug et al. } \\
2007 \text {, Islam } \\
2009, \text { IUCN } \\
\text { BD 2015 }\end{array}$ & $\begin{array}{lr}\text { Zug et al. } \\
2007, \text { Chakma } \\
2009, \text { Hasan } \\
\text { et al. } 2014 \text {, } \\
\text { IUCN } \text { BD } \\
2015\end{array}$ & \begin{tabular}{lr}
\multicolumn{2}{l}{ Chakma } \\
$2009, \quad$ Hasan \\
et al. 2014 , \\
IUCN & BD \\
2015 &
\end{tabular} & $\begin{array}{l}\text { Tyler 1961, } \\
\text { Zug et al. } \\
\text { 2007, Chakma } \\
\text { 2009, Hoskin } \\
\text { 2011, Naher et } \\
\text { al. 2013, } \\
\text { Hasan et al. } \\
2014\end{array}$ & $\begin{array}{l}\text { Zug et al. } \\
2007, \\
\text { Chakma } \\
\text { 2009, Hasan } \\
\text { et al. 2014, } \\
\text { IUCN BD } \\
2015\end{array}$ & $\begin{array}{l}\text { Zug et al. } 2007, \\
\text { Chakma } \\
\text { Hasan et al. 2009, } 2014 \text {, } \\
\text { Tkaczenko et al. } \\
\text { 2014, IUCN BD } \\
2015\end{array}$ \\
\hline
\end{tabular}

Notes: $\mathrm{A}=$ Araneae, $\mathrm{C}=$ Coleoptera, $\mathrm{D}=$ Diptera, $\mathrm{H}=$ Homoptera, $\mathrm{He}=$ Hemiptera, $\mathrm{Hy}=$ Hymenoptera, $\mathrm{I}=\mathrm{Isoptera}, \mathrm{L}=$ Lepidoptera, $\mathrm{O}=$ Orthoptera, $\mathrm{Z}=$ Zygoptera 
The species of Hemidactylus have been seen in different habitats like on walls on which they could easily capture prey (Fig. 2a and b). They sometimes show very good camouflage with nature in their habitats (Fig. 2d, camouflage with tree and 2f, camouflage with grass).

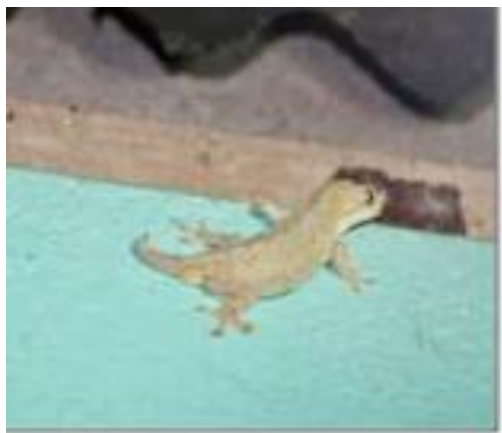

a. Yellow-green House Gecko (H. flaviviridis)

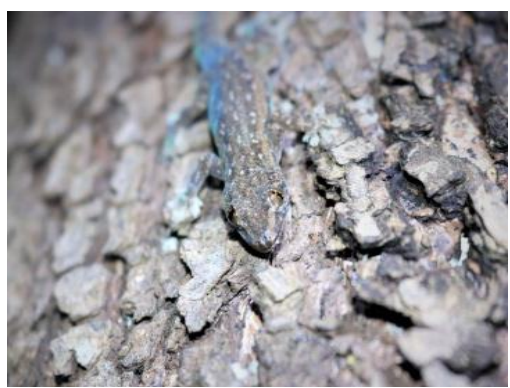

d. Garnot's Gecko (H. garnotii)

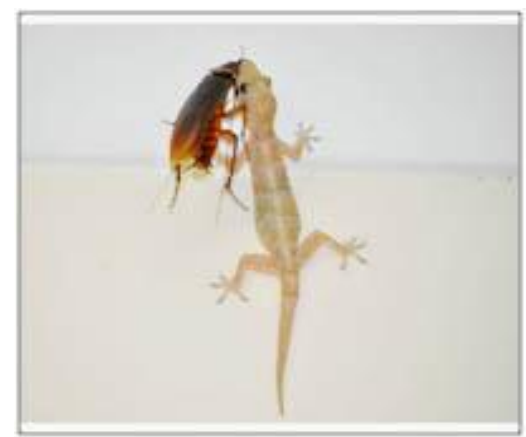

b. Common House Gecko (H. frenatus)

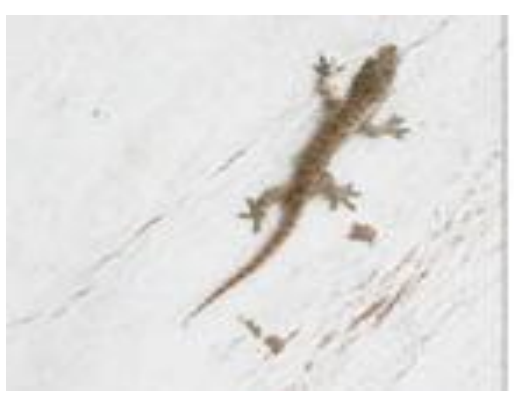

e. Brook's House Gecko (H. brookii)

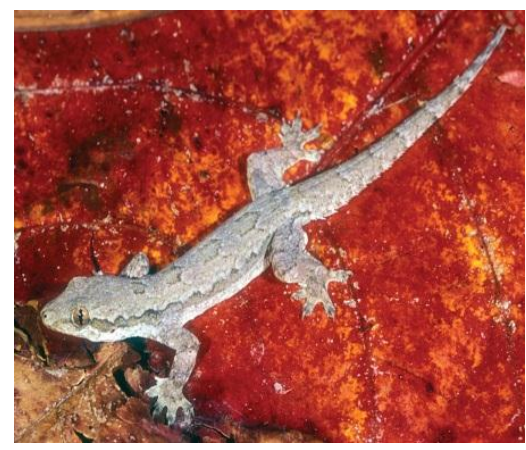

c. Flat-tailed Gecko (H. platyurus)

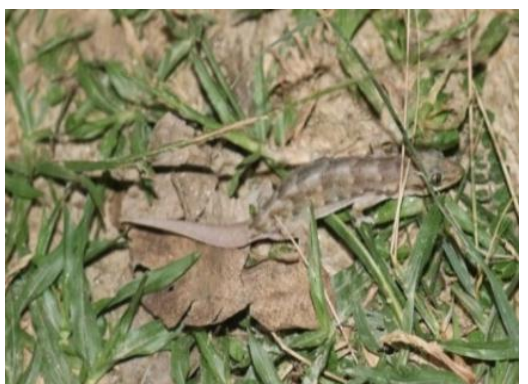

f. Oriental Leaf-toad Gecko (H. bowringii)

Fig. 2. The species of the Hemidactylus genus are presented here from Bangladesh. Photo credit: Md. Fazle Rabbe $(\mathbf{a}, \mathbf{d}, \mathbf{e}, \mathbf{f}) ;$ M. Firoj Jaman (b); Internet (c).

The review of previous records shows that five species of Hemidactylus are found in different parts of Bangladesh. Among them, $H$. bowringii has been reported from northwestern region only and $H$. garnotii from southwestern region only and the other three species are found in all three studied regions of Bangladesh (Table 3). H. brookii, H. flaviviridis and H. frenatus are found in all kinds of habitats, such as roadside, human habitation, wall, tree, etc. $H$. bowringii was also found in grassland and $H$. garnotii was only found in tree (Table 3).

The majority of geckos are insectivores and few are herbivores and carnivores (Daniel 2002). Tyler studied the feeding behavior of $H$. frenatus in 1961 and recently the feeding ecology of this species studied by Naher et al. (2013) through gut analysis. H. frenatus used to eat dipterans (Tyler 1961) and coleopterans (Naher et al. 2013) mostly as their food. The feeding ecology and habitat of H. platyurus and $H$. frenatus was studied by Tkaczenko et al. (2014) through behavioral observation and insect sampling revealing preference of insects of the order of Araneae, Coleoptera, Diptera, Homoptera, Hymenoptera, Lepidoptera, and Orthoptera. It reflects similarity with the behavior of $H$. brookii and $H$. flaviviridis studied by Chakma 2009 (Table 2). Our observation suggests that Hemidactylus species have a preference for dipterans especially for mosquitoes which is a harmful insect for human. We have also observed the consumption of cockroaches by $H$. flaviviridis and grasshopper by $H$. garnotii. All six species are found eating various groups of insects (Table 3). The preying method of all species is found more or less similar. Initial movement towards prey was strikingly rapid. After that, when Hemidactylus got near to the prey, it took some time and then suddenly grab the object. Parves and Alam (2015) reported about predation of congeneric $H$. frenatus by $H$. flaviviridis. 
Table 3. Diversity of species of Hemidactylus genus and their habitat and food preferences.

\begin{tabular}{|c|c|c|c|c|}
\hline Region & Place & Species & Habitat & Preys on \\
\hline \multirow{4}{*}{ 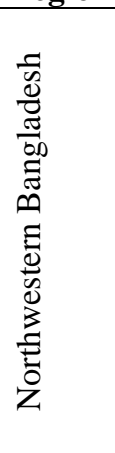 } & Rangpur, Thakurgaon & H. bowringii & $\begin{array}{l}\text { Grassland (Cynodon dactylon), Tree } \\
\text { (Mangifera indica), Wall }\end{array}$ & Spider, Ant \\
\hline & $\begin{array}{l}\text { Nilphamari, Thakurgaon, } \\
\text { Rangpur }\end{array}$ & H. brookii & $\begin{array}{l}\text { Human Habitation, Tree (Eucalyptus sp. } \\
\text { Artocarpus heterophyllus, Carica } \\
\text { papaya, Swietenia mahagoni) }\end{array}$ & Mosquito, Cricket \\
\hline & $\begin{array}{l}\text { Dinajpur, Nilphamari, } \\
\text { Rajshahi, Thakurgaon, } \\
\text { Rangpur }\end{array}$ & H. frenatus & $\begin{array}{l}\text { Human Habitation, Tree (Mangifera } \\
\text { indica), Wall }\end{array}$ & - \\
\hline & $\begin{array}{l}\text { Dinajpur, Nilphamari, } \\
\text { Rajshahi, Thakurgaon, } \\
\text { Rangpur }\end{array}$ & H. flaviviridis & $\begin{array}{l}\text { Human Habitation, Tree (Mangifera } \\
\text { indica, Averrhoa carambola), Wall, } \\
\text { Roadside }\end{array}$ & $\begin{array}{l}\text { Moth, Housefly, } \\
\text { Bug }\end{array}$ \\
\hline \multirow{3}{*}{ 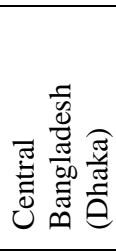 } & $\begin{array}{l}\text { Ramna, National } \\
\text { Botanical Garden }\end{array}$ & H. brookii & $\begin{array}{l}\text { Wall, Tree (Swietenia mahagoni, } \\
\text { Albizzia procera) }\end{array}$ & Mosquito, Ant \\
\hline & $\begin{array}{l}\text { Ramna, DU campus, } \\
\text { National Botanical Garden }\end{array}$ & H. flaviviridis & Wall, Human Habitation & $\begin{array}{l}\text { Cockroach, } \\
\text { Mosquito }\end{array}$ \\
\hline & $\begin{array}{l}\text { Ramna, DU campus, } \\
\text { National Botanical Garden }\end{array}$ & H. frenatus & Wall, Human Habitation & - \\
\hline \multirow{4}{*}{ 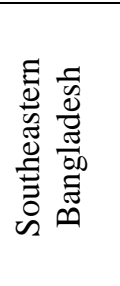 } & Chittangong, Noakhali & H. brookii & $\begin{array}{l}\text { Tree (Soneratia apetala, Phoenix } \\
\text { sylvestris, Zizyphus jujuba), Wall }\end{array}$ & Mosquito, Ant \\
\hline & Noakhali & H. garnotii & Tree (Soneratia apetala) & Grasshopper \\
\hline & $\begin{array}{l}\text { Widely distributed in } \\
\text { Bangladesh }\end{array}$ & H. frenatus & $\begin{array}{l}\text { Tree (Phoenix sylvestris, Zizyphus } \\
\text { jujuba), Wall }\end{array}$ & Beetle, Ant, Moth \\
\hline & $\begin{array}{l}\text { Widely distributed in } \\
\text { Bangladesh }\end{array}$ & H. flaviviridis & Tree (Phoenix sylvestris), Wall & - \\
\hline
\end{tabular}

\section{Chromosomal Variation}

Karyotypic analysis has been done for only about $11 \%$ of house gecko species using conventional cytogenetic methods (Patawang and Tanomtong 2015). The chromosome number in house geckos varies from 40 to 46 and $H$. garnotii $(3 n=70)$ reported as triploid parthenogenetic (Patawang and Tanomtong 2015). Kluge and Eckardt (1969) and later Patawang and Tanomtong (2015) found 40 chromosomes in $H$. frenatus, $H$. brookii and $H$. flaviviridis. Both $H$. bowringii and $H$. platyurus have 46 chromosomes (Nakamura 1931, Kluge and Eckardt 1969, Darevsky et al. 1984, Patawang and Tanomtong 2015) and the variation in chromosomal morphology is shown in Table 4.

Table 4. Chromosome characteristics of the genus Hemidactylus.

\begin{tabular}{|c|c|c|c|c|c|c|c|}
\hline \multicolumn{2}{|c|}{ Species Name } & H. bowringii & H. brookii & H. flaviviridis & H. frenatus & H. garnotii* & H. platyurus \\
\hline \multirow{4}{*}{ 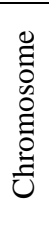 } & Morphology & $46 \mathrm{R}$ & $4 \mathrm{~V}$ and $36 \mathrm{R}$ & $40 \mathrm{R}$ & $40 \mathrm{R}$ & $6 \mathrm{X}, 18 \mathrm{~V}, 46 \mathrm{R}$ & $44 \mathrm{~T}$ and $2 \mathrm{~A}$ \\
\hline & $\begin{array}{l}\text { Chromosome } \\
\text { no. }(2 n)\end{array}$ & 46 & 40 & 40 & 40 & 70 & 46 \\
\hline & Bi-armed & 0 & 4 & - & 0 & 6 & 0 \\
\hline & Uni-armed & 46 & 36 & - & 40 & 64 & 46 \\
\hline \multicolumn{2}{|c|}{ References } & $\begin{array}{l}\text { Nakamura } \\
\text { 1931, Kluge } \\
\text { and Eckardt } \\
\text { 1969, } \\
\text { Darevsky et } \\
\text { al. } 1984\end{array}$ & $\begin{array}{l}\text { Bhatnagar } \\
\text { 1962, Kluge } \\
\text { and Eckardt } \\
\text { 1969, De Smet } \\
\text { 1981, 5= } \\
\text { Darevsky et al. } \\
1984\end{array}$ & $\begin{array}{l}\text { Kluge and } \\
\text { Eckardt 1969, } \\
\text { Darevsky et al. } \\
1984\end{array}$ & $\begin{array}{l}\text { Patawang } \\
\text { and } \\
\text { Tanomtong } \\
2015\end{array}$ & $\begin{array}{l}\text { Kluge and } \\
\text { Eckardt 1969, } \\
\text { Darevsky et al. } \\
1984\end{array}$ & $\begin{array}{l}\text { Patawang and } \\
\text { Tanomtong } \\
2015\end{array}$ \\
\hline
\end{tabular}

$* 3 \mathrm{~N} ; \mathrm{A}=$ Acrocentric, $\mathrm{R}=$ Rods graded to dots, $\mathrm{T}=$ Telocentric, $\mathrm{V}=\mathrm{V}$-shaped, $\mathrm{X}=\mathrm{X}$-shaped 
Hemidactylus is an important genus of reptile group because of its insectivorous habit. But a thorough study on the feeding and breeding ecology of the species of this genus has not been done yet in Bangladesh. So, comprehensive studies on behavioral ecology are therefore recommended through this review. In Bangladesh, the studies on the ecology and chromosomal variation are not sufficient that could provide adequate information. The previous studies show that most of the species have more or less similar chromosome morphology. Karyological analysis should be done using modern techniques as most of the work in this field had been done before 1990s. All the six Hemidactylus species are protected by Bangladesh Wildlife (Conservation and Security) Act, 2012 and included in Schedule II. So, to protect lizard, wildlife laws should be implemented. To eradicate myth and local prejudice about lizards, awareness creation and conservation education among local people should be increased.

\section{REFERENCES}

Al-Amri, I. S. S. 2012. Reproductive cycle of the House Gecko, Hemidactylus flaviviridis, in Oman in relation to morphological and ultrastructural changes and plasma steroid concentrations with reference to localisation of progesterone receptors. Ph.D. Thesis, University of Portsmouth, England.

Bansal, R. and K. P. Karanth. 2010. Molecular phylogeny of geckos (Squamata: Gekkonidae) of the Indian subcontinent reveals a unique Indian radiation and an Indian origin of Asian house geckos. Mol. Phylogenet. Evol. 57(1): 459-465.

Bauer, A. M., T. R. Jackman, E. Greenbaum, V. B. Giri and A. de Silva. 2010. South Asia supports a major endemic radiation of Hemidactylus geckos. Mol. Phylogenet. Evol. 57: 343-352.

Bhatnagar, A. N. 1962. Chromosome cytology of two lizards, Riopa punctata Gmelin and Hemidactylus brookii Grey. Caryologia. 15(2): 335-349.

Carranza, S. and E. N. Arnold. 2006. Systematics, biogeography, and evolution of Hemidactylus geckos (Reptilia: Gekkonidae) elucidated using mitochondrial DNA sequences. Mol. Phylogenet. Evol. 38: 531545.

Carranza, S. and E. N. Arnold. 2012. A review of the geckos of the genus Hemidactylus (Squamata: Gekkonidae) from Oman based on morphology, mitochondrial and nuclear data, with descriptions of eight new species. Zootaxa. 3378: 1-95.

Chakma, S. and M. A. Islam. 2009. Hemidactylus. In: S. M. H. Kabir, M. Ahmed, A. T. A. Ahmed, A. K. A. Rahman, Z. U. Ahmed, Z. N. T. Begum, M. A. Hassan, M. Khondker (ed.). Encyclopedia of Flora and Fauna of Bangladesh. Volume 25, Amphibians and Reptiles. Asiatic Society of Bangladesh, Dhaka, pp. 88-92.

Church, G. 1962. The reproductive cycles of the Javanese House Geckos, Cosymbotus platyurus, Hemidactylus frenatus, and Peropus mutilatus. Copeia. 2: 262-269.

Daniel, J. C. 2002. The Book of Indian Reptiles and Amphibians. Bombay Natural History Society, Oxford University Press. 238 pp.

Darevsky, I. S., L. A. Kupriyanova and V. V. Roshchin. 1984. A new all-female triploid species of gecko and karyological data on the bisexual Hemidactylus frenatus from Vietnam. J. Herpetol. 18(3): 277-284.

De Smet, W. H. O. 1981. Description of the orcein strained karyotypes of 27 lizard species (Lacertilia, Reptilia) belonging to the families Iguanidae, Agamidae, Chameleonidae and Gekkonidae. Acta. Zool. Pathol. 76: 35-72.

GBIF.org (13 ${ }^{\text {th }}$ October 2018) GBIF Occurrence Download www.gbif.org 
Gibbons, J. W., D. E. Scott, T. J. Ryan, K. A. Buhlmann, T. D. Tuberville, B. S. Metts, J. L. Greene, T. Mills, Y. Leiden, S. Poppy and C. T. Winne. 2000. The Global Decline of Reptiles, Déjà Vu Amphibians: Reptile species are declining on a global scale. Six significant threats to reptile populations are habitat loss and degradation, introduced invasive species, environmental pollution, disease, unsustainable use, and global climate change. Bio. Sci. 50(8): 653-666.

Hasan, M. K., M. M. H. Khan and M. M. Feeroz. 2014. Amphibians and Reptiles of Bangladesh- A Field Guide. Arannayk Fundation, Dhaka. 191 pp.

Hoskin, C. J. 2011. The invasion and potential impact of the Asian House Gecko (Hemidactylus frenatus) in Australia. Austral. Ecol. 36: 240-251.

IUCN Bangladesh. 2015. Red List of Bangladesh, Reptiles and Amphibians. IUCN, International Union for Conservation of Nature, Bangladesh Country Office, Dhaka, Bangladesh. Vol. 4. 319 pp.

Kluge, A. G. and Eckardt, M. J. 1969. Hemidactylus garnotii Dumeril and Bibron, a triploid all-female species of gekkonid lizard. Copeia. 4: 651-664.

Mitchell, J. C. and G. R. Zug. 1988. Ecological observations on the gecko Hemidactylus brookii in Nepal. Amphibia-Reptilia 9: 405-413.

Naher, K., A. B. M. S. Alam, S. Rahman and M. M. Kabir. 2013. Gut contents of Common House Gecko, Hemidactylus frenatus (Schlegel, 1836) in Jahangirnagar University Campus, Savar, Bangladesh. Bangladesh J. Zool. 41(2): 229-232.

Nakamura, K. 1932. Studies on reptilian chromosomes III. Chromosomes of some geckos. Cytologia. 3: 156-168.

Parves, N. and S. M. I. Alam. 2015. Hemidactylus flaviviridis (Reptilia: Gekkonidae): Predation on congeneric Hemidactylus frenatus in Dhaka, Bangladesh. Herpetol. Bull. 132: 28-29.

Patawang, I. and Tanomtong, A. 2015. Karyological analysis of Asian House Gecko (Hemidactylus frenatus) and Frilly House Gecko (H. platyurus) from Northeastern Thailand. National Genetics Conference., pp. 308-313.

Rabbe, M. F., M. M. Alam and M. M. Rahman. 2017. Geographic distribution of Hemidactylus bowringii (Oriental Leaf-toed Gecko). Herpetol. Rev. 48(4): 811.

Sanyal, M. K. and M. R. N. Prasad. 1967. Reproductive cycle of the Indian House Lizard, Hemidactylus flaviviridis Rüppell. Copeia. 3: 627-633.

Tkaczenko, G. K., A. C. Fischer and R. Weterings. 2014. Prey preference of the Common House Geckos Hemidactylus frenatus and Hemidactylus platyurus. Herpetol. Notes 7: 483-488.

Tyler, M. J. 1961. On the diet and feeding habits of Hemidactylus frenatus (Dumeril and Bibron) (Reptilia, Gekkonidae) at Rangoon, Burma. Trans. Roy. Soc. S. Aust. 84: 45-49.

Uetz, P., P. Freed and J. Hošek. 2016. The Reptile Database. Available from: http://www.reptiledatabase.org (accessed 29 December 2016).

Vanderduys, E. P. and A. S. Kutt. 2012. Is the Asian house gecko, Hemidactylus frenatus, really a threat to Australia's biodiversity? Aust. J. Zool. 60: 361-367.

Walter, E. and J. R. Meshaka, 1994. Reproductive cycle of the Indo-Pacific gecko, Hemidactylus garnotii, in South Florida. Fla. Sci. 57(1-2): 6-9.

Yamamoto, Y. and H. Ota. 2006. Long-term functional sperm storage by a female Common House Gecko, Hemidactylus frenatus, from the Ryukyu Archipelago, Japan. Curr. Herpetol. 25(1): 39-40.

Zug, G. R., J. V. Vindum and M. S. Koo. 2007. Burmese Hemidactylus (Reptilia, Squamata, Gekkonidae): taxonomic notes on tropical Asian Hemidactylus. Proc. Calif. Acad. Sci. 58(19): 391-408. 